Fort Hays State University

FHSU Scholars Repository

Master's Theses

Graduate School

Fall 1935

\title{
The Lime Content of Rocks of The Upper Cretaceous System of Ellis County, Kansas
}

G. Lawrence Rarick

Fort Hays Kansas State College

Follow this and additional works at: https://scholars.fhsu.edu/theses

Part of the Chemistry Commons

\section{Recommended Citation}

Rarick, G. Lawrence, "The Lime Content of Rocks of The Upper Cretaceous System of Ellis County, Kansas" (1935). Master's Theses. 237.

DOI: 10.58809/HAGZ6341

Available at: https://scholars.fhsu.edu/theses/237

This Thesis is brought to you for free and open access by the Graduate School at FHSU Scholars Repository. It has been accepted for inclusion in Master's Theses by an authorized administrator of FHSU Scholars Repository. For more information, please contact ScholarsRepository@fhsu.edu. 
THE LIME CONTENT

OF ROCKS OF THE UPPER CRETACEOUS SYSTEM

OF EIIIS COUNTY, KANSAS

\section{being}

A Thesis presented to the Graduate Faculty in partial fulfillment of the requirements for the Degree of Master of Science

\section{by}

\section{Lawrence Rarick}

Bachelor of Science, Bachelor of Arts
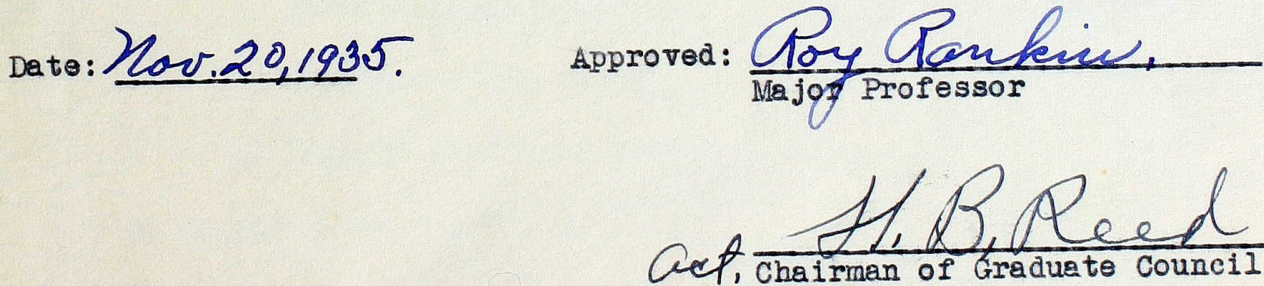

FORT HAYS KANSAS STATE COLLEGE 


\title{
ACKNOWLEDGMENT
}

\begin{abstract}
I acknowledge a debt of gratitude to Professor Roy Rankin, Head of the Chemistry Department, for assistance rendered to me in this study, particularly in suggesting the problem. His continued interest has been an inspiration and help throughout the investigation.
\end{abstract}


TABLE OF CONTEINTS

Page

I. INTRODUCTION • • • • • • • • • • • • 1

II. GEOGRAPHY AND LOCATION • . . . . . . • • • 3

III. TOPOGRAPHY • • • • • • • • • • • • 4

IV. STRATIGRAPHY • • • . • . . • • • • • 5

V. GEOLOGY OF UPPIR CRETACEOUS SYSTEM • • • • • • • 9

A. Niobrara Formation . . . . . . . 9

1. Snoky Hill chalk member - • • • • 9

2. Fort Hays limestone member . • . . 10

B. Carlile Shale . . . . . . . . . 11

1. Blue Hill shale member • • • • • Il

2. Fairport chalky shale nember . • • 12

C. Greenhorn Limestone • • • • • • • 13

1. Pfeifer shale member • • • • • 13

2. Jetmore chalk member . . . . . . 13

3. Hartland shale member . . . . • 14

4. Lincoln limestone member . • • • 14

D. Graneros Shale . . . . . . . . 16

E. Dakota Sandstone . . . . . . • • 17

VI. METHOD OF COLLECTING ROCK SAIPLES • • • • • • 18 
TABLE OF CONTENTS (Cont.)

Page

VII. LABORATORY PROCEDURE - • . • • • • • • • 20

A. Preparation of samples for the analysis . . 20

B. Removal of insoluble matter and silica . . . 21

C. Removal of iron and aluminum oxides . . . . 22

D. Precipitation of calcium as calcium oxalate . 23

E. Standardization of potassium permanganate solution. . . . . . . . . . 25

F. Volumetric determination of calcium . . . . 27

VIII. RESULTS • • • • • • • • • • • • • • 28

IX. SUMMLARY AIND CONCLUSION • • • • • • • • • 44

X. BIBLIOGRAPHY • • • • • • • • • • • 50 


\section{INTRODUCTION}

The report which is being submitted here is the result of several weeks of field and laboratory work investigating the rocks of the Upper Cretaceous System of Ellis County, Kansas. The writer has attempted to consider the subject primarily from a chemical viewpoint although much of the background for the work has been of a geological nature. There has been no attempt to give a complete chemical analysis of the rocks of the Upper Cretaceous System, but rather a more or less thorough analysis in regard to the percentage of lime that the rocks of the various formations and members in respective parts of the county may contain. Also the attempt has been made to determine the consistency of the percentage of lime in a given member in various parts of the county and also of different beds of a given member in the same locality. The possibility of the existence of limestone of a percentage sufficiently high to be used for cattle feeding and for the manufacturing of lime has also been investigated. So far as the writer has been able to learn, there has been no work done on the chemical composition of the rocks of the Upper Cretaceous System of Ellis County, other than at Yocemento. Undoubtedly enalytical work was done there during the time the cement factory was operating. However, the plant has boen closed for a good many years and no printed materials are available regarding the nature of the enterprise. 
Much of the work has been based upon the geological report of N.W. Bass, entitled "Geologic Investigations in Western Kans28." 


\section{GEOGRAPHY AND LOCATION}

Ellis County lies only a short distance north and west of the center of Kansas. It is approximately 30 miles square and contains about 576,000 acres. The main line of the Union Pacific railroad between Kansas City and Denver passes through the county in an east-west direction. Hays is the largest town in the county with a population of 5,000 ; it also is the county seat. The Fort Hays Kansas State College and a large experiment station indicate that Hays is the leading educational town of Ellis County. Ellis, the next largest town, has a population of about 2,000 , and is a division point of the Union Pacific railroad. There are nine other small towns in the county, many of which are inland villages. Federal Highway No. $40 \mathrm{~S}$ passes through the county paralleling the railroad and across the county from north to south we find State Highway No. 1 . Well graded roads are kept in good repair giving access to all parts of the county with the exception of the extremely rough northwest section.

The county as a whole is quite level and practically treeless, except for narrow lines of trees along the principal streams and for small groves surrounding farm homes.

Wheat raising is the chief industry, although there is an increasing tendency toward diversified farming. The rougher portions of the county, bordering the smoky Hill and Saline rivers, are largely given over to cattle raising with a sheep ranch located here and there. 


\section{TOPOGRAPHY}

Topographically Elis County is located at the easterm margin of the High Plains. Its characteristic topographic features are broad, relatively flat, upland benches, deeply cut by the main drainage channels. These main streams flow east, and their valleys are markedly steeper on the south sides than on the north sides. The broad benches rising gently westward, margined by cliffs that have eastward fronts, are controlled by the harder rocks that crop out at the surface. The highest bench which occupies the high divides in the west half of the county is made up of the resistant Tertiary "mortar beds" of the ogallalla formation. The next bench is supported by the Fort Hays limestone of the Niobrara formation, and the lowest bench, located in the southern and eastern portion of the county, by the Greenhorn limestone.

1. The altitude of the surface above sea level ranges from 2,400 feet near the southwest corner of the county to 1700 feet in the northeastern part. The maximum relief in the southwestern part of the county is 360 feet in 4 miles, and at places along the saline and Smoky Hill rivers has an average fall in a straight line across the county of approximately 10 feet to the mile.

1. Bass, N. W. Geologic Investigations in Westem Kansas. (In Kansas State Geological Survey. Bulletin 11, Lawrence, Kansas.) 


\section{STRATIGRAPHY}

The rocks exposed in Ellis County are of Quaternary, Tertiary and Cretaceous age. The lowest rocks exposed appear along the smoky Hill river in the southeastern part of the county. The thick shale members of the Cretaceous system make gently graded, soil-mantled slopes over a large part of the county, but are well exposed in the extreme southwestern part and along the Saline river in the northerm part. The top beds of the Cretaceous section represented here are best exposed in the northwestern part of the county, and the tertiary rocks in the western part. The flood plains of the streams are occupied by the Quaternary deposits.

The following table gives the outstanding features of the formations exposed. 
TABLE $I^{2 .}$

Stratigraphic Section of Outcropping Rocks in Ellis County, Kansas.

\begin{tabular}{|c|c|c|c|}
\hline $\mathrm{AGE}$ & FORMATION AND MEMBER & LITHOLOGICAL THIO & KEIVESS \\
\hline Recent & & $\begin{array}{l}\text { Alluvium in } \\
\text { stream flood } \\
\text { plains. }\end{array}$ & $0-40$ feet \\
\hline Pleistocene & $\begin{array}{l}\text { McPherson (?) For- } \\
\text { mation }\end{array}$ & $\begin{array}{l}\text { Gravel terraces } \\
\text { along Smoky } \\
\text { Hill and Saline } \\
\text { rivers. }\end{array}$ & $0-20$ \\
\hline $\begin{array}{l}\text { Pliocene and } \\
\text { late Miocene }\end{array}$ & $\begin{array}{l}\text { Ogalalla Forma- } \\
\text { tion }\end{array}$ & $\begin{array}{l}\text { Gravel, sand, } \\
\text { clay, and "mor- } \\
\text { tar beds" upon } \\
\text { high divides } \\
\text { throughout coun- } \\
\text { ty. }\end{array}$ & $0-75$ \\
\hline \multirow[t]{2}{*}{$\begin{array}{l}\text { Upper Creta- } \\
\text { ceous }\end{array}$} & $\begin{array}{l}\text { Niobrara Forma- } \\
\text { tion. Smoky Hill } \\
\text { chalk member. }\end{array}$ & $\begin{array}{l}\text { Chalky shale, in- } \\
\text { terbedded with } \\
\text { buttle chalk. Weath- } \\
\text { ers pure white, yel- } \\
\text { low orange. Forms } \\
\text { badlands. Top not } \\
\text { exposed. }\end{array}$ & 100 \\
\hline & $\begin{array}{l}\text { Fort Hays lime- } \\
\text { stone member. }\end{array}$ & $\begin{array}{l}\text { Massively bedded } \\
\text { cream-colored } \\
\text { chalky limestone. } \\
\text { Makes prominent } \\
\text { bluffs bordering } \\
\text { main streams. }\end{array}$ & 55 \\
\hline
\end{tabular}

2. Ibid. 
TABLE I (cont.)

AGE FORMATION AND MEMBER
LITHOLOGICAL
CHARACTER

THICKNESS CHARACTER

\begin{tabular}{|c|c|c|c|}
\hline $\begin{array}{l}\text { Upper Cre- } \\
\text { taceous } \\
\text { (cont.) }\end{array}$ & $\begin{array}{l}\text { Carlile Shale } \\
\text { Blue Hill shale } \\
\text { member. }\end{array}$ & $\begin{array}{l}\text { Gray-black fissile } \\
\text { clay shale; with Co- } \\
\text { dell sandstone bed } \\
\text { at top, and several } \\
\text { layers of calcareous } \\
\text { septarian concre- } \\
\text { tions. Thins south- } \\
\text { westward. }\end{array}$ & $175-215$ \\
\hline & $\begin{array}{l}\text { Fairport chalky } \\
\text { shale member. }\end{array}$ & $\begin{array}{l}\text { Chalky shale inter- } \\
\text { bedded with thin } \\
\text { layers of chalky } \\
\text { limestone, which in- } \\
\text { creases in number } \\
\text { toward the base. }\end{array}$ & $85-115$ \\
\hline & $\begin{array}{l}\text { Greenhorm limestone } \\
\text { Pfeifer shale } \\
\text { member. }\end{array}$ & $\begin{array}{l}\text { Chalky shale inter- } \\
\text { bedded with thin } \\
\text { layers of soft chalk- } \\
\text { y limestone. Top } \\
\text { bed known as "fence- } \\
\text { post limestone"... } \\
\text { Makes low bench. }\end{array}$ & 20 \\
\hline & $\begin{array}{l}\text { Jetmore chalk } \\
\text { member. }\end{array}$ & $\begin{array}{l}\text { Alternating thin } \\
\text { beds of chalky lime- } \\
\text { stone and chalky } \\
\text { shale. Limestone in } \\
\text { upper half abundant- } \\
\text { ly fossiliferous... } \\
\text { makes pronounced bed. }\end{array}$ & 20 \\
\hline & $\begin{array}{c}\text { Greenhorn limestone } \\
\text { Hartland shale. }\end{array}$ & $\begin{array}{l}\text { Chalky shale with } \\
\text { few thin beds of } \\
\text { chalky limestone... } \\
\text { makes gentle slope. }\end{array}$ & 35 \\
\hline
\end{tabular}


TABLE I (cont.)

AGE FORMATION AND MEMBER ITHOLOGICAL
CHARACTER
CHARACTER

\begin{tabular}{|c|c|c|c|}
\hline $\begin{array}{l}\text { Upper Cre- } \\
\text { taceous } \\
\text { (cont.) }\end{array}$ & $\begin{array}{l}\text { Lincoln limestone } \\
\text { member. }\end{array}$ & $\begin{array}{l}\text { Yellowish, tan- } \\
\text { weathering chalky } \\
\text { shale with hard } \\
\text { thin-bedded, fine- } \\
\text { ly laminated crys- } \\
\text { talline limestone } \\
\text { at top and base... } \\
\text { Makes low bench. }\end{array}$ & 20 feet \\
\hline & Graneros Shale & $\begin{array}{l}\text { Dark bluish-black } \\
\text { shale with bed of } \\
\text { sandy ironstone } \\
\text { near base and a } \\
\text { few sandy calcar- } \\
\text { eous lenses above. }\end{array}$ & $32-40$ \\
\hline & Dakota Sandstone & $\begin{array}{l}\text { Fine-grained white } \\
\text { sandstone, irregu- } \\
\text { larly bedded, and } \\
\text { red, white, and } \\
\text { mottled clay and } \\
\text { sandy shale. Base } \\
\text { not exposed. }\end{array}$ & $20+$ \\
\hline
\end{tabular}


V. GEOLOGY OF UPPER CRETACEOUS SYSTEM ${ }^{3}$.

A. Niobrara Formation.

In Kansas the Niobrara Formation has been divided into two members--the Smoky Hill chalk member above and the Fort Hays limestone below. In the western and northwestern part of the county approximately 150 feet of the basal part of the Niobrara formation is in places exposed in bare bluffs and badlands.

1. Smoky Hill Chalk Member.

About 100 feet of the basal part of the smoky Hill chalk member is exposed below the overlapping Ogallala formation in Ellis county. It consists of marl beds alternating with chalk and thin beds of clay. The member occupies a relatively broad area in the western part of the county, forming the gently rolling table-lands above the Fort Hays limestone and below the Ogallala formation. The chalky shale and soft chalk beds break down into smooth, gently graded slopes through most of its area of outcrop, but in some localities, particularly in the northward-facing slopes, it makes bare, intricateIy dissected badlands. The differential weathering results in buttes

3. Ibid. 
and scarps of fantastic shapes that range in color from white through yellow to orange and orange-red.

\section{Fort Hays Limestone Member.}

The Fort Hays limestone member of the Niobrara formation in Ellis County is a massively bedded cream-colored chalk or very chalky limestone. The individual beds of chalky limestone range in thickness from 6 inches to 6 feet and average about $2 \frac{1}{4}$ to 3 feet. These beds are separated by thin layers, 1 to 4 inches thick, of light gray chalky clay shale. The beding is thinner toward the top of the member, and the upper beds commonly weather almost pure white. The Fort Hays member appears to be slightly coarser in texture and somewhat harder than the chalk of the overlying Smoky Hill. The individual beds are much thicker than those of the Smoky Hill, the Smoky Hill having much the greater shale content. The individual beds and series of beds are persistent, with only a slight change in thickness over large areas.

Because the Fort Hays limestone is considerably harder than the underlying Carlile shale, it commonly stands in vertical bluffs that cap a steep, barren shale slope. In Ellis County the valley of the Seline river is bordered with such bluffs throughout the area of outcrop of the Fort Hays member.

The Fort Hays member of the Niobrara is quite persistent and regular in its thickness and general character throughout western Kansas. 
B. The Carlile Shale.

The Carlile shale is a chalky and clay shale, about 300 feet thick. The upper two-thirds is composed predominantly of gray-black fissile clay shale, and the lower third of chalky shale and thin beds of chalky limestone. In Ellis County it is separated into the Blue Hill shale member above and the Fairport chalky shale member below.

1. Blue Hill Shale Member.

The Blue Hill shale member occupies a broad belt of gently graded, grassed slopes in southern and eastern Ellis County and a narrow band of bare, steep slopes along the Saline river in the northern part. Its thickess ranges between 215 feet near the northeast corner of the county and 175 feet near the southwest corner. The member is made up of gray-black noncalcareous clay shale, which at several horizons contains large calcareous concretions, and in the uppermost 25 feet of gritty shale or sandstone. At the top of the Blue Hill shale member is a very fine grained sandstone, including a few layers of sandy shale. Below this sandy shale is an indurated sandstone bed 5 to 6 feet thick that weathers to $a$ bright tan color and forms a curved cliff face. The basal sandy material grades into the shale below and in most of 1 ts outcrops forms gentle slopes. Gray-black fissile noncalcareous clay shale contain- 
ing several layers of calcareous concretions makes up the remainder of the Blue Hill Shale member. Gypsum crystals are not uncommon to this member.

2. Fairport Chalky Shale Member.

The Fairport chalky shale member of the Carlile shale occupies a broad area of low relief in the southern and eastern parts of the county. It has a range of thickness from 85 feet in the northeastern part of Ellis County to 115 feet near the southwest corner. The Firport chalk is composed throughout of calcareous shale, including thin beds of chalky limestone, which occur in greatest abundance toward. the base of the member. On fresh exposures it is bluish, but 1ts weathered surface is a light orange-tan color. The lower half has, in addition, a pink tinge, which gives it a fresh color. This member, particularly the lower half, is lithologically not unlike the underlying Greenhorn limestone, but the fossils contained in it furnish the basis for separation. The upper boundary of the Fairport member is not so sharply defined throughout the county as the base. In good exposures it can readily be determined by the calcareous character of the Fairport shales and their weathered orange-tan color, in contrast with the noncalcareous character and gray-black color of the overlying shales and their stickiness when wet.

The lower member of the carlile shale continues to increase in thickness westward beyond the boundaries of Ellis County. The boundary between the Fairport member and the Greenhorn limestone is placed at the top of the "fence-post limestone" bed. 


\section{Greenhorn Limestone.}

The entire formation of the Greenhorn Limestone occupies approximately only 15 percent of the surface of Ellis county. The formation has a thickmess of nearly 100 feet. We find that the Greenhorn formation is extensively exposed in the southern and southeastern parts of the county and extends a few miles up the Saline river in the northeastern part.

\section{Pfeifer Shale Member.}

The Pfeifer shale member exposed near Pfeifer, Ellis County, is capped by the "fence-post limestone" bed, so-called because it is extensively quarried and used for fence posts throughout the region of its outcrop. The pfeifer member is 19 to 21 feet thick and consists of alternating layers of chalky shale and chalky limestone. On fresh exposure the entire mass exhibits a blue color, but on weathering it becomes a light tan or cream. In general, the member produces gently graded slopes. Its outcrop throughout this region is often marked by white mounds of the overburden removed in quarrying the "fence-post limestonen bed.

2. Jetmore Chalk Niember.

The Jetmore chalk member underlying the Pfeifer shale mem- 
ber is 20 feet of interbedded chalky shale and chalky limestone. The chalky limestone beds of this member are harder than those of the overlying Pfeifer member, and the uppermost bed, which is almost a foot in thickness, is hard, and characteristically forms a bench with its blocks scattered along the edge. The chalky limestone beds become thinner and less numerous in the lower part of the Jetmore member and grade into the calcareous shale of the underlying Hartland member.

Because of the predominance of beds of hard, white, chalky limestone, the member weathers in steep, almost bare, light-colored slopes.

3. Hartland Shale Member.

The Hartland shale member lies just below the Jetmore chalk member. It has a thickness of about 35 feet and contains a few thin beds of soft chalky limestone and a few thin layers of clay. The Hartland shale member grades into the overlying Jetmore member without much change in lithology, so it is difficult to determine a distinct dividing line between the two members.

\section{Lincoln Limestone Member.}

The Iincoln limestone member, the basal member of the Green- 
horn limestone, consists of about 20 feet of chalky shales and thin beds of light-gray, chalky limestone and of hard, finely banded, darkcolored, crystalline limestone. The beds of crystalline limestone are most abundant at the base and top of the member, and emit a strong bituminous odor when broken. As a whole, this member has a much yellower color than other members of the Greenhorn limestone. 


\section{Graneros Shale Formation.}

The Granerous shale occupies only a narrow strip in the southeastern part of Ellis county along the Smoky Hill river. It is made up predominantly of blue-black fissile noncalcareous clay shale. Numerous thin lenses of sandy shale, sandstone, sandy limestone, and ironstone concretions are interbedded with the shale. Selenite crystals are commonly strewn over the surface, and the shale has a bitter taste. 
E. Dakota Sandstone Formation.

Only the uppermost 18 to 20 feet of the Dakota sandstone is exposed in Ellis county and that in an area of only a few acres. The Dakota sandstone consists, from the top down, of 5 feet of heavily bedded, fine grained, light gray sandstone, containing an abundance of carbonized plant fragments; a zone 1 foot thick of pyrite concretions embedded in sandstone; and 8 feet of massive, fine grained sandstone. The rocks between the base of the sandstone and the river are concealed by alluvium. 


\section{METHOD OF COLLECTING ROCK SAIPLES}

All of the rock samples under consideration for this problem were obtained through personal visitations from surface outcroppings of the strata in various localities. Whenever possible the samples were taken from the large outcroppings. Representative samples were secured from a given stratum and whenever there appeared to be a difference in rock structure in the same outcropping, samples were taken from each type of rock structure. The samples were taken from a wide range covering the greater part of the county, including the various formations and members of the Upper Cretaceous system. A geological map of Ellis County published by the State Geological Survey was used as a guide in helping to locate and to distinguish the various strata. However, the obtaining of the rock samples themselves was done more or less by trial and error, since the geological map showed only which stratum was nearest the surface and gave no definite indication as to where an outcropping might occur. Therefore it was necessary to arive in a car on section lines until an outcropping of a rock formation was observed. By taking careful observation of the speedometer reading of the car, as to miles covered, the exact position of the outcropping rock formation could be located, thereby confirming the formation and member from 
which the sample was obtained. A cold chisel and hamer were used in dislodging the rock sample from the main stratum. Care was taken that enough of the stratum was chiseled away to be assured that the sample obtained had not been exposed to weathering. Each sample was placed in a wide mouth jar. These in turn were labeled as to the formation, with the exact section, towship, and range from which the sample had been obtained. 


\section{IAABORATORY PROCEDURE ${ }^{4}$}

A. Preparation of Samples for the Analysis.

Each sample when brought into the laboratory from the field trip consisted of rather large rough rock fragments. It was, of course, necessary that these rocks be in a finely powdered form. The samples were ground to a fine powder in an iron mortar. The powdered rock was then dried in an oven at $110^{\circ} \mathrm{C}$. for two hours.

4. Talbot, Henry P.---Quantitative Chomical Analysis, p. 184-200. Fngelender, Carl J.---Elementary Quantitative Analysis. 
B. Removal of Insoluble Matter and Silica.

Two portions of the same dried sample were weighed into a 250 c.c. beaker, 50 c.c. of hydrochloric acid (Sp. Gr. of 1.12) were added and the beaker was covered with a watch glass, and placed upon the electric hot plate to evaporate to dryness. About threetenths of a gram of the sample were used in each trial. When evaporated to dryness a few cubic centimeters of water and 5 c.c. of concentrated hydrochloric acid were added and again taken down to dryness on the hot plate. After the residue was allowed to cool, water was added and also a few cubic centimeters of dilute hydrochloric acid. The whole wes then boiled and the insoluble silicates filtered off. 
C. Removal of Iron and Aluminum Oxides.

In the separation of iron and aluminum oxide, dilute ammonium hydroxide (Sp. Gr. 0.95) was added to the above filtrates, until just ammoniacal; 5 c.c. of saturated bromine water were added. The solution was heated to boiling and a few crystels of ammonium chloride added and more ammonium hydroxide, if the odor of ammonia was not noticeable. The solution was filtered while hot. When the precipitate of the iron and aluminum hydroxides was large the precipitates were redissolved in dilute hydrochloric acid and reprecipitated as described above. When the precipitate of the hydroxides was small this reprecipitation was omitted. The filtrate contained the calcium in solution. 


\section{Precipitation of Calcium as Calcium Oxalate.}

In the determination of calcium, the filtrate from the above separation was neutralized with dilute ammonium hyaroxide, and then made distinctly acid with hyärochloric acid. Two drops of methyl orange were used as an indicator. The calculated volume of ammonium oxalate solution (40 gr. of $\left(\mathrm{NH}_{4}\right)_{2} \cdot \mathrm{C}_{2} \mathrm{O}_{4} \cdot \mathrm{H}_{2} \mathrm{O}$ per liter) required to precipitate all the calcium in the sample was then added, assuming the sample to be pure calcium carbonate. Two cubic centimeters in excess of the calculated volume were measured out.

The acidified filtrates were warmed and the precipitating agent added drop by arop, from a pipette, with constant stirring of the solution. Whenever a precipitate formed during the adition of the ammonium oxalate solution, enough hydrochloric acid was added to redissolve it. After the addition of the ammonium oxalate, diIute ammonium hydroxide ( $\mathrm{Sp}$. Gr. 0.95) was added from a pipette until the indicator turned yellow. The precipitated calcium oxalate was allowed to settle for at least a half-hour and then decanted through a filter. The filtrate was then tested for completed precipitation by adding a few cubic centimeters of ammonium oxalate solution. The calcium oxalate was redissolved in the beaker with wam dilute hydrochlor- 
ic acid, the acid being poured through the filter. The filter was washed several times with hot water and then emmonium hydroxide was poured through it. This solution was diluted to 250 cubic centimeters and brought to bolling; 5 cubic centimeters of ammonium oxalate solution were added, and ammonia in slight excess. This was boiled for two minutes and set aside for a half-hour. The reprecipitated calcium oxalate was filtered off upon the filter first used, and washed. free from chlorides.

The precipitated calcium oxalate could then be converted directly into calcium oxide by ignition, but when several analyses are to be made this is considered a longer method than the determination made volumetrically, due to the time required for ignition and weighing. Therefore, the method of volumetric determination of calcium was used. 
E. Standardization of $\mathrm{KMnO}_{4}$.

The volumetric determination of calcium requires that a standard solution of a suitable oxidizing agent be used in titrating the liberated oxalic acid. Potassium permanganate was chosen as the oxidizing agent. Only a liter of the potassium permanganate solution was made up at a time, and it was used no longer than over a period of two weeks. This gave the assurance that the standard would not change in composition. Great care was also taken to exclude any organic matters in making up the standard solution.

In preparing the standard solution, about 3.25 grams of $\mathrm{KWnO}_{4}$ were dissolved in a liter of water and boiled for several minutes. The solution was poured into a liter bottle and set aside for several days. The impurities were then filtered out by means of a sintered glass filter connected to a suction pump. The solution was then poured into a glass-stoppered liter bottle made of dark glass. For the standardization of the potassium permanganate solution, sodium oxalate was used. The sodium oxalate used was a primary standard meeting the specifications of the American Chemical Society and assaying $99.95 \%$ pure sodium oxalate.

Two portions of the dried sodium oxalate, approximately .25 gram each, were used. Each portion was aissolved in about $200 \mathrm{c.c}$. 
26.

of water and heated almost to boiling. While still hot 5 c.c. of concentrated sulfuric acid were added by means of a pipette to the oxalate solution. The solutions were then ready to be titrated with the potassium permanganate; care was taken not to allow the temperature to drop below $70^{\circ} \mathrm{C}$. during the titration. The end point was a faint permanent pink, indicating the complete oxidation of the free oxalic acid.

By being careful, it was possible to reach the exact end point in the titration, saving not only the time of having to back titrate with oxalic acid, but also the need of obtaining the comparison of the strengths of the permanganate solution with oxalic acid. The normality of the potassium permanganate was found by dividing the weight of the sodium oxalate by the product of the number of cubic centimeters of permanganate used and the gram-mill1equivalent weight of sodium oxalate.

Normality of $\mathrm{KMnO}_{4}=\frac{\text { Wt. of } \mathrm{Na}_{2} \mathrm{C}_{2} \mathrm{O}_{4}}{\mathrm{c}_{\cdot \mathrm{c}} \cdot \mathrm{KNnO}_{4} \mathrm{xm} \cdot \mathrm{m} \cdot \text { of } \mathrm{Na}_{2} \mathrm{C}_{2} \mathrm{O}_{4}}$ 
F. Volumetric Determination of Calcium.

With the potassium permanganate stancardized the volumetric determination of calcium could be made. The celcium oxalate was washed from the filter paper into a $400 \mathrm{c.c}$. beaker, and about $200 \mathrm{c} . \mathrm{c}$. of water added. The filter paper which had held the precipitate was also aded to make certain of no loss of calcium oxalate. After heating the solution almost to the boiling point $5 \mathrm{c.c}$. of concentreted sulfuric acid were carefully added by means of a pipette. The titration of the liberated oxalate ions with standard potassium permanganate was conducted in the same manner as standardization process described above.

To insure accurate results check runs were made on every sample. If the runs did not check to less than two-tenths of a percent calcium per sample, the samples were run again until check results were obtained. The percentages used in this problem, and found in the tables which follow, are the average of the initial and check runs.

The percentage of lime in the sample was determined by multiplying together the number of cubic centimeters of potassium permanganate used, the normality of the potassium permanganate, the grammilliequivalent weight of calcium oxide and 100; the resulting product was then divided by the weight of the sample.

Percent Calcium Oxide $=\frac{\text { c.c. } \times \text { Normality } \times \text { m.e. CaO } \times 100}{\text { Wt. of Sample }}$ 


\section{RESULTS}

The sample containing the highest percentage of lime was taken from the Fort Hays limestone member of the Niobrara formation, Sec. 33, T. 12 S., R. 16 W. The percentage of lime was 54.26 . The sample containing the lowest percentage of lime ran but .31 percent. This sample was taken from Sec. 22, T. 13 S., R. 19 W. from the Blue Hill shale member of the Carlile shale formation.

Table II is simply a condensed record of the samples analyzed. It shows the township, range, and section from which the samples were obtained. Also, the percentage of lime, calcium, and calcium carbonate for each sample is given.

Table III gives the lime content of each sample according to the member from which it was obtained. This enables one to see how the percentages of the various samples in a given member or formation compare with each other. Tables IV and $V$ are quite similar to Table II. The only difference is that the comperison is made in Table IV on a basis of percentage of calcium and in Table $\mathrm{V}$ on a basis of percentage of calcium carbonate.

The average lime content for each member was then determined. The Fort Hays limestone member ran the highest average percentage of lime--52.06\%. The Greenhorn limestone formation ran next highest with 
an average of 50.02 percent of lime, with the others lower as is shown at the bottom of Table III.

It is interesting to note the veriation in percent of lime of samples taken from the same location and same member, but from different rock beds. Sample 18 taken from Sec. 28, T. 13S., R. 20\%. ran 51.36\% lime, while sample 19 taken from a bed just a few feet higher ran but $44.60 \%$ lime. These samples were taken from the smoky Hill chalk member.

Samples 28, 29, and 30 were taken from the same location but from beds approximately 5 feet apart. These samples were also taken from the smoky Hill chalk member, Sec. 33, T. 11 S., R. 20 W. Sample 28 ran $39.88 \%$ lime, sample $29 \operatorname{ran~} 49.80 \%$ and sample 30 contained $48.69 \%$ lime. Observations made of these beds indicated in color form a considerable difference in chemical content. Samples taken from the same location of the Fairport chalky shale member, but from different beds, showed the greatest variation in lime content of any analyzed. Sample 36 contained $26.87 \%$ lime, while sample 37 ran $46.17 \%$. The location was Sec.9, T. 15 S., R. 20 W. 
Map of Ellis County

(Location of each sample represented by dot ad-

jacent to sample number as found in Table II.)

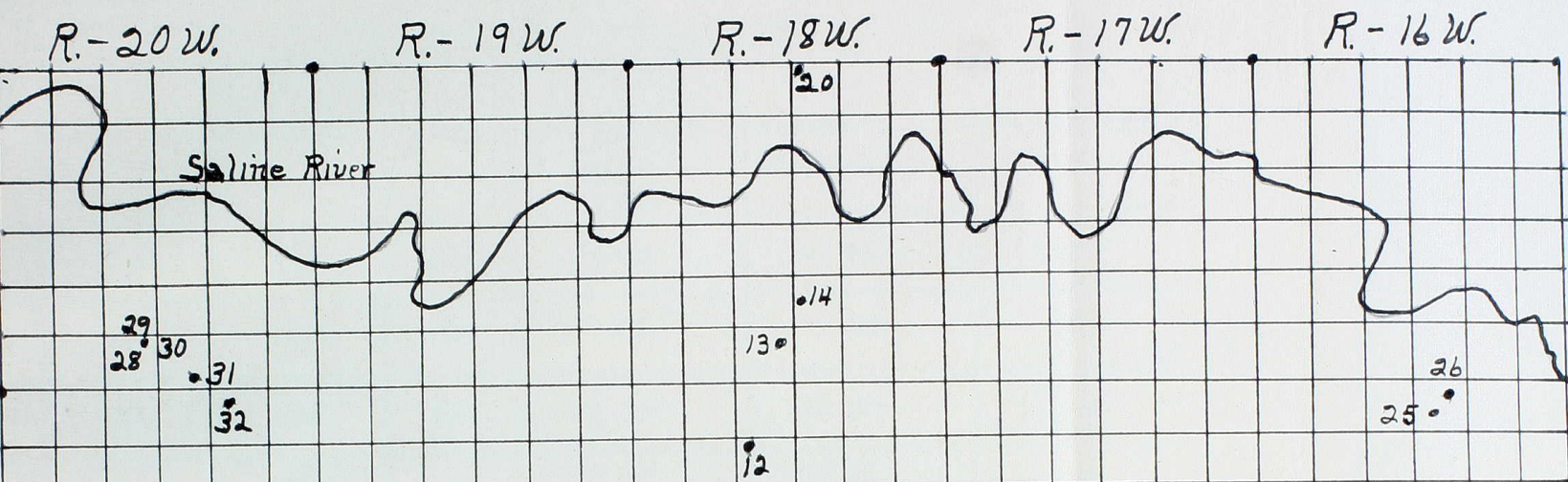

27

Ellis

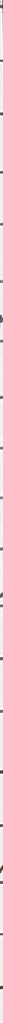


TABLE II

(Indicating sample number, location of samples, and percentage of lime, percentage of calcium, and percentage of calcium carbonate in each.)

\begin{tabular}{|c|c|c|c|c|c|c|}
\hline $\begin{array}{l}\text { Sample } \\
\text { Number }\end{array}$ & Section & Township & Range & $\begin{array}{l}\text { Percentage } \\
\text { of Lime }\end{array}$ & $\begin{array}{l}\text { Percentage } \\
\text { of Calcium }\end{array}$ & $\begin{array}{l}\text { Percentage } \\
\text { of } \mathrm{CaCo}_{3}\end{array}$ \\
\hline 1 & 1 & $14 \mathrm{~S}$ & $19 w$. & 48.36 & 34.55 & 85.86 \\
\hline 2 & 22 & 135. & 19 प. & .31 & .228 & .568 \\
\hline 3 & 27 & $13 \mathrm{~S}$ & 19 . & 46.99 & 33.63 & 83.56 \\
\hline 4 & 10 & $13 S$ & 19 . & 52.90 & 37.84 & 94.50 \\
\hline 5 & 29 & $15 S$. & $17 w$. & 52.39 & 37.40 & 92.95 \\
\hline 6 & 32 & $15 \mathrm{~s}$. & $17 \mathrm{~W}$. & 52.29 & 37.38 & 92.88 \\
\hline$\eta$ & 30 & $15 \mathrm{~S}$. & $16 \mathrm{~T}$. & 51.73 & 37.02 & 91.99 \\
\hline 8 & 13 & $15 \mathrm{~s}$. & $17 w$. & 51.69 & 36.93 & 91.75 \\
\hline 9 & 22 & $13 \mathrm{~S}$ & $18 \mathrm{~W}$. & 53.94 & 38.55 & 95.80 \\
\hline 10 & 4 & $13 \mathrm{~S}$. & $18 \mathrm{~W}$. & 52.14 & 37.31 & 92.70 \\
\hline 11 & 3 & $13 \mathrm{~s}$ & $18 \%$. & 53.71 & 38.39 & 95.40 \\
\hline 12 & 9 & 125. & $18 w$. & 46.20 & 32.95 & 81.86 \\
\hline 13 & 33 & $11 \mathrm{~S}$. & $18 \%$ & 52.76 & 37.68 & 93.63 \\
\hline 14 & 27 & $11 \mathrm{~S}$. & $18 \%$. & .355 & .332 & .799 \\
\hline 15 & 15 & $13 \mathrm{~S}$. & $20 W$. & 52.67 & 36.76 & 93.50 \\
\hline 16 & 16 & 135. & $20 \%$. & 49.00 & 35.02 & 87.00 \\
\hline 17 & 20 & $13 \mathrm{~s}$ & $20 w$. & 47.11 & 33.77 & 83.88 \\
\hline 18 & 28 & $13 \mathrm{~s}$. & 20W. & 51.36 & 36.56 & 90.89 \\
\hline 19 & 28 & $13 \mathrm{~S}$. & $20 \%$ & 44.60 & 31.76 & 78.94 \\
\hline
\end{tabular}


32.

TABLE II (cont.)

\begin{tabular}{|c|c|c|c|c|c|c|}
\hline $\begin{array}{l}\text { Sample } \\
\text { Number }\end{array}$ & Section & Township & Range & $\begin{array}{l}\text { Percentage } \\
\text { of Lime }\end{array}$ & $\begin{array}{l}\text { Percentage } \\
\text { of Calcium }\end{array}$ & $\begin{array}{l}\text { Percentage } \\
\text { of } \mathrm{CaCo}_{3}\end{array}$ \\
\hline 20 & 3 & $11 \mathrm{~s}$. & 18 W. & 50.85 & 36.31 & 90.22 \\
\hline 21 & 5 & $14 S$ & 16 W. & 48.40 & 36.23 & 86.01 \\
\hline 22 & 5 & $14 S$ & 16 . & 47.08 & 33.61 & 83.56 \\
\hline 23 & 33 & $12 S$. & $16 \mathrm{~W}$ & 54.26 & 38.78 & 96.37 \\
\hline 24 & 27. & $12 S$. & $16 \%$. & 52.85 & 37.77 & 93.85 \\
\hline 25 & 3 & 12S. & 16 W. & 49.40 & 35.30 & 87.50 \\
\hline 26 & 3 & 12S. & $16 \%$. & 27.11 & 19.37 & 48.16 \\
\hline 27 & 21 & $12 S$. & $20 \%$. & 45.38 & 32.44 & 80.60 \\
\hline 28 & 33 & 115. & $20 \mathrm{w}$. & 39.88 & 24.82 & 64.60 \\
\hline 29 & 33 & 115. & 20 . & 49.80 & 35.60 & 88.40 \\
\hline 30 & 33 & $11 S$. & 20 W. & 48.69 & 34.79 & 86.46 \\
\hline 31 & 34 & $11 S$. & 20\%. & 50.07 & 35.78 & 88.93 \\
\hline 32 & 2 & 125. & 20 . & 54.18 & 38.72 & 96.20 \\
\hline 33 & 29 & $15 S$. & 18พ. & 51.76 & 36.99 & 91.93 \\
\hline 34 & 29 & $15 S$. & $18 \mathrm{~W}$. & 40.19 & 28.72 & 71.37 \\
\hline 35 & 16 & $15 \mathrm{~s}$. & 19 . & 51.21 & 36.60 & 90.95 \\
\hline 36 & 9 & $15 \mathrm{~S}$. & $20 \%$ & 26.87 & 19.20 & 47.71 \\
\hline 37 & 9 & $15 S$. & $20 \%$. & 46.17 & 32.97 & 81.96 \\
\hline 38 & 34 & $15 S$. & $16 w$. & 49.88 & 35.65 & 88.59 \\
\hline 39 & 27 & $15 S$. & $16 \%$. & 43.00 & 30.74 & 76.37 \\
\hline
\end{tabular}


TABLE III

(Inaicating percentage of lime content in various members.)

\begin{tabular}{|c|c|c|c|c|c|c|c|}
\hline sample & $\begin{array}{l}\text { percent- } \\
\text { age }\end{array}$ & sample & $\begin{array}{l}\text { percent- } \\
\text { age }\end{array}$ & sample & $\begin{array}{l}\text { percent- } \\
\text { age }\end{array}$ & sample & $\begin{array}{l}\text { percent- } \\
\text { age }\end{array}$ \\
\hline 4 & 52.95 & 1 & 48.36 & 2 & .31 & 21 & 48.40 \\
\hline 10 & 52.20 & 3 & 47.1 & 14 & .355 & 22 & 47.08 \\
\hline 12 & 46.20 & 9 & 53.95 & & & 25 & 49.40 \\
\hline 16 & 49.00 & 11 & 53.68 & & & 26 & 27.11 \\
\hline 17 & 47.11 & 13 & 52.76 & & & 35 & 51.21 \\
\hline 18 & 51.36 & 15 & 52.67 & & & 36 & 26.87 \\
\hline 19 & 44.60 & 20 & 50.85 & & & 37 & 46.17 \\
\hline 27 & 45.38 & 23 & 54.26 & & & & \\
\hline 28 & 39.88 & 24 & 52.85 & & & & \\
\hline 29 & 49.80 & 32 & 54.18 & & & & \\
\hline 30 & 48.69 & & & & & & \\
\hline 31 & 50.07 & & & & & & \\
\hline
\end{tabular}

Average of Runs

\begin{tabular}{l|l|l|l|}
\hline $48.27 \%$ & $52.06 \%$ & $.332 \%$ & $42.32 \%$ \\
\hline
\end{tabular}




\section{TABLE III (cont.)}

\begin{tabular}{l|l|l|l|l|l}
\multicolumn{2}{l|}{ Greenhorn } & Graneros Shale & \multicolumn{2}{|l}{ Dakota Sandstone } \\
\hline sample & $\begin{array}{l}\text { percent- } \\
\text { age }\end{array}$ & sample & $\begin{array}{l}\text { percent- } \\
\text { age }\end{array}$ & sample & $\begin{array}{l}\text { percent- } \\
\text { age }\end{array}$ \\
\hline 5 & 52.35 & 38 & 49.88 & 39 & 43.00 \\
\hline 6 & 52.33 & & & & \\
\hline 7 & 51.80 & & & & \\
\hline 8 & 51.67 & & & & \\
\hline 33 & 51.76 & & & & \\
\hline
\end{tabular}

Average of Runs

\begin{tabular}{l|l|l|}
\hline $50.02 \%$ & $49.88 \%$ & $43.00 \%$ \\
\hline
\end{tabular}




\section{TABLE IV}

(Indicating percentage of Calcium content in various members.)

\begin{tabular}{|c|c|c|c|c|c|c|c|}
\hline sample & $\begin{array}{l}\text { percent- } \\
\text { age }\end{array}$ & sample & $\begin{array}{l}\text { percent- } \\
\text { age }\end{array}$ & sample & $\begin{array}{l}\text { percent- } \\
\text { age }\end{array}$ & sample & $\begin{array}{l}\text { percent- } \\
\text { age }\end{array}$ \\
\hline 4 & 37.84 & 1 & 34.55 & 2 & .228 & 21 & 36.23 \\
\hline 10 & 37.31 & 3 & 33.63 & 14 & .332 & 22 & 36.61 \\
\hline 12 & 32.95 & 9 & 38.55 & & & 25 & 35.30 \\
\hline 16 & 35.02 & 11 & 38.39 & & & 26 & 19.37 \\
\hline 17 & 33.77 & 13 & 37.68 & & & 35 & 36.60 \\
\hline 18 & 36.56 & 15 & 36.76 & & & 36 & 19.20 \\
\hline 19 & 31.76 & 20 & 36.31 & & & 37 & 32.97 \\
\hline 27 & 32.44 & 23 & 38.78 & & & & \\
\hline 28 & 24.82 & 24 & 37.77 & & & & \\
\hline 29 & 35.60 & 32 & 38.72 & & & & \\
\hline 30 & 34.79 & & & & & & \\
\hline 31 & 35.78 & & & & & & \\
\hline
\end{tabular}


TABLE IV (cont.)

\begin{tabular}{c|c|c|c|c|c}
\multicolumn{2}{c|}{ Greenhorn } & \multicolumn{2}{c|}{ Graneros shale } & \multicolumn{2}{c}{ Dakota sandstone } \\
\hline sample & percentage & sample & percentage & sample & percentage \\
\hline 5 & 37.40 & 38 & 35.66 & 39 & 30.74 \\
\hline 6 & 37.38 & & & & \\
\hline 8 & 37.02 & & & & \\
\hline 33 & 36.93 & & & & \\
\hline 34 & 36.99 & & & & \\
\hline
\end{tabular}


TABLE $V$

(Indicating percentage of Calcium Carbonate in various members.)

Niobrara Formation

Carlile Shale

\begin{tabular}{|c|c|c|c|c|c|c|c|}
\hline \multicolumn{2}{|c|}{ Smoky Hill } & \multicolumn{2}{|c|}{ Fort Hays } & \multicolumn{2}{|c|}{ Blue Hill } & \multicolumn{2}{|c|}{ Fairport chalk } \\
\hline sample & $\begin{array}{l}\text { percent- } \\
\text { age }\end{array}$ & sample & $\begin{array}{l}\text { percent- } \\
\text { age }\end{array}$ & sample & $\begin{array}{l}\text { percent- } \\
\text { age }\end{array}$ & sample & $\begin{array}{l}\text { percent- } \\
\text { age }\end{array}$ \\
\hline 4 & 94.50 & 1 & 85.86 & 2 & .568 & 21 & 86.01 \\
\hline 10 & 92.70 & 3 & 83.56 & 14 & .799 & 22 & 83.56 \\
\hline 12 & 81.86 & 9 & 95.80 & & & 25 & 87.50 \\
\hline 16 & 87.00 & 11 & 95.40 & & & 26 & 48.16 \\
\hline 17 & 83.88 & 13 & 93.63 & & & 35 & 90.95 \\
\hline 18 & 90.89 & 15 & 93.50 & & & 36 & 47.71 \\
\hline 19 & 78.94 & 20 & 90.22 & & & 37 & 81.96 \\
\hline 27 & 80.60 & 23 & 96.37 & & & & \\
\hline 28 & 64.60 & 24 & 93.85 & & & & \\
\hline 29 & 88.40 & 32 & 96.20 & & & & \\
\hline 30 & 86.46 & & & & & & \\
\hline 31 & 88.93 & & & & & & \\
\hline
\end{tabular}


TABLE V (cont.)

\begin{tabular}{|c|c|c|c|c|c|}
\hline sample & percentage & sample & percentage & sample & percentage \\
\hline 5 & 92.95 & 38 & 88.59 & 39 & 76.37 \\
\hline 6 & 92.88 & & & & \\
\hline 7 & 91.99 & & & & \\
\hline 8 & 91.75 & & & & \\
\hline 33 & 91.93 & & & & \\
\hline 34 & 71.37 & & & & \\
\hline
\end{tabular}


\begin{tabular}{l|llllllllllll} 
Samplene & 5 & 10 & 15 & 20 & 25 & 30 & 35 & 40 & 45 & 50 & 55 & 60
\end{tabular}

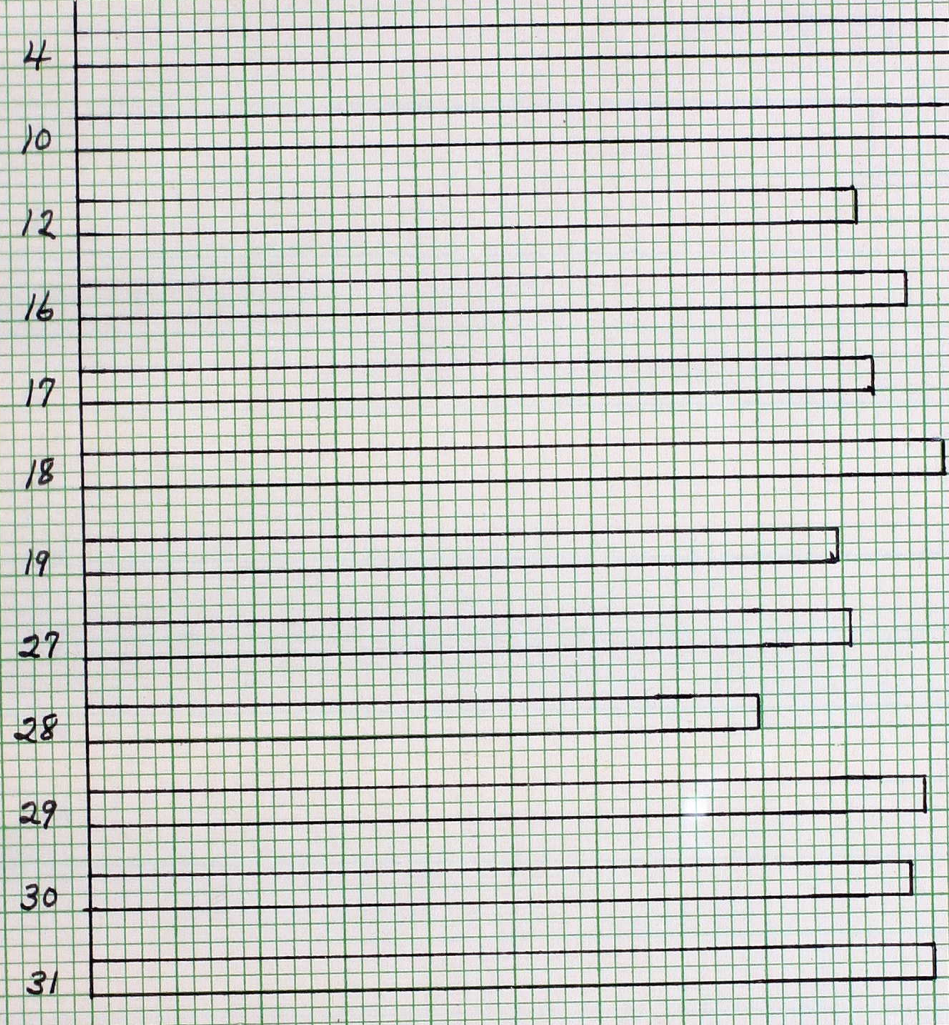




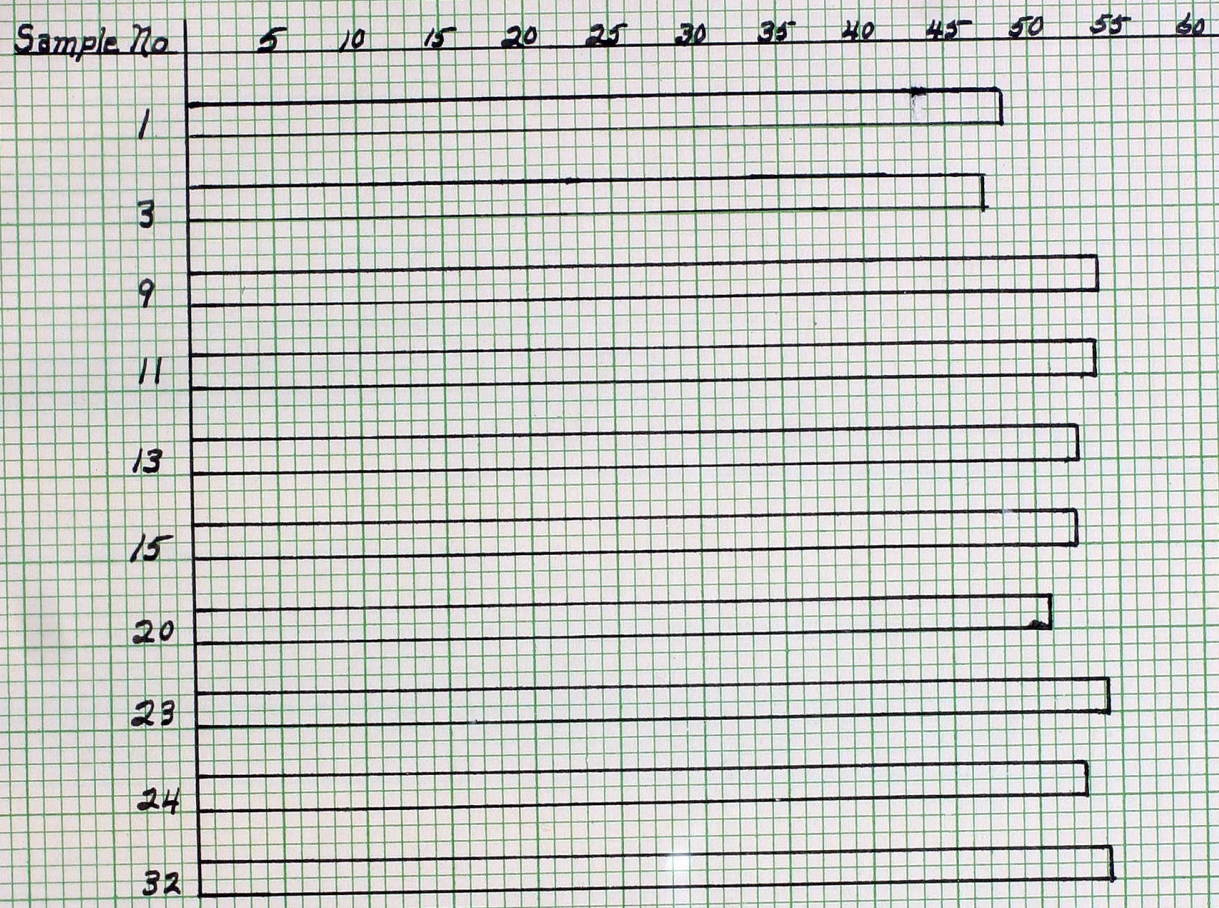




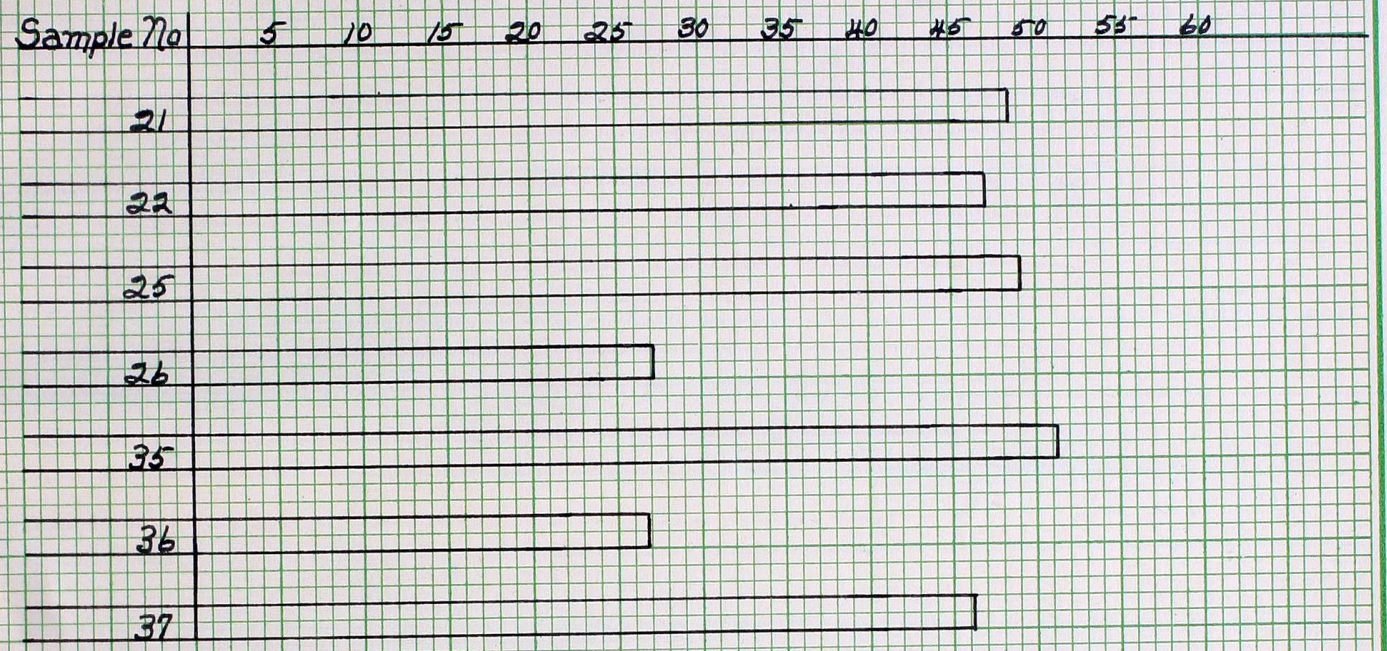




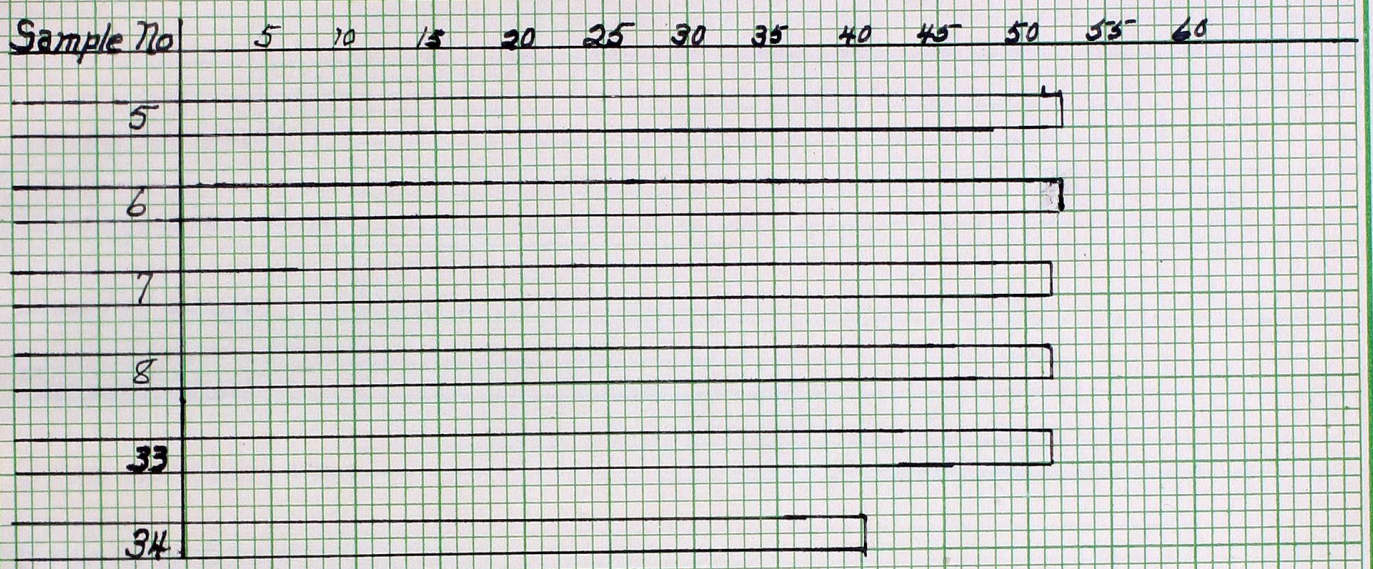




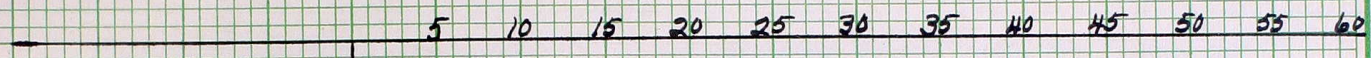

Smoky Hill Chalk

Fort Hays Limestone

Blue Hill Shale

Fairport Chalk

GreenhornLimestone

Graneros Shale

DaKota Sanstone 


\section{SUMMARY AND CONCLUSION}

The lime content of the samples taken from the beds of the Smoky Hill chalk member do not show as great a variation as might be expected considering thet many of the beds appear to contain more shale than chalk. The high runs $52.95 \%$ lime and the low $39.88 \%$ lime, a variation of approximately $13 \%$. Ten out of twelve of the samples run higher than $45 \%$ lime, which indicates that this member runs fairly high in lime content.

The Fort Hays limestone member shows less variation among its samples in percent lime content than the Smoky Hill chalk member. The difference between the high and low is but approximately $6 \%$ and eight out of ten samples run from $50.85 \%$ to $54.26 \%$ lime. The Fort Hays limestone member not only averages the highest in lime content, but the percentage of lime in its beds throughout the county is also quite constant.

The Blue Hill shale member seems to be consistent in its lack of lime, running less then half a percent in two runs taken from wi dely separate localities in the county.

The Fairport chelky shale member of the Carlile shale shows the widest variation in lime content among its samples of all the members, with a high of $51.21 \%$ and a low of $26.87 \%$. This variation can possibly be explained by the presence of alternating chalk and shale 
beds in greater thlckness and number than in the other members. It might be interesting to repeat here the result of the findings in Sec. 9, T. 15 S., R. $20 \mathrm{~W}$. in the Fairport member. From a large outcropping of shale the sample runs $26.87 \%$; from the same locality but from a chalk bed a few feet lower the sample runs $46.17 \%$, a variation of approximately $20 \%$.

Five of the six samples taken from the Greenhorn limestone formation run quite constent in percentege of lime, the difference in range lying between $51.67 \%$ and $52.35 \%$. Sample 34 , however, drops approximately $11 \%$ below the others. This is due to the fact that sample 34 was taken from a thin bed of shale. Sample 33, taken from the same location but from a chalk bed, runs $51.76 \%$. The indications are that the Greenhorn formation runs fairly constant in percentage of lime excluding the thin beds of shale.

The Graneros Shale formation, which is primarily composed of sandstone beds, runs surprisingly high in lime. The sample taken from the narrow strip of Graneros shale exposed in Ellis County runs $49.88 \%$ lime.

The sample taken from the Dakota Sandstone formation contains $43 \%$ lime, which is a relatively high lime content for sandstone beds.

It might be well to mention to the reader some of the interesting economic possibilities that Ellis County offers relative to 
this problem. Probably one of the most important economic uses of limestone is its use in the production of Portland cement. The expansion of the Portland cement industry in the last twenty years is due to extensive road-building programs, to the development of reinforced concrete constructions, and to the adaptability and uniformity of the material. Not only walls and piers, but girders of concrete are now freely used. Bridge piers, tunnels, dams, and canal walls are built of concrete as well as sidewalks, steps, garage and factory floors, and building foundations. One reason for the almost universal use of Portland cement is the comparative ease of working; another is its strength which increases with age; a third is its uniformity, which permits calculations of strength as reliable as those made for structural steel. The necessary raw materials for the production of portland cement are lime in the form of limestone and clay or shale. The latter must contain silica, iron oxide, and alumina.5. These raw materials, in the form of limestone and shales, are abundantly found in the Upper Cretaceous formation of Ellis County. Lime, more properly called quicklime, is the oxide of calcium, Cao, and is obtained by driving the carbon dioxide out of limestone. The reaction $\mathrm{CaCO}_{3} \rightleftharpoons \mathrm{CaO}+\mathrm{CO}_{2}$ is reversible; it runs to the right if the carbon dioxide is removed. Limestone suitable for the production of lime should contain no less than $50 \%$ lime ${ }^{6}$; as the preceding tables

5. Riegel, Fil Raymond--Industrial Chemistry, pp. 90-98. 6. Willaman, John F.--Vocational Chemistry, pp. 100-101. 
show, many limestone beds of this region are suitable for lime production.

Lime as quicklime is used for mortar with a mixture of lime, sand, and water. Mortar has been largely displaced by Portland cement, but seven-tenths of the lime made is still used for structural purposes, either as mortar, or mixed with cement or plaster. ${ }^{7}$. Lime is also used in the chemical industries, such as ammonia soda, gas purification, paper making, and tanning. Hydrated lime is used to make sand bricks, and as a fertilizer; it is also one of the raw materials for bleaching powder.

Lately much attention has been given to the possibility of using ground limestone in cattle fattening rations, especially in this section of the country in which legume hays are not grown. These sections do, however, produce silage crops including corm, as well as the grain sorghums and sweet sorghums, which, however, are inferior to the legume hays in their calcium content. The Kansas Agricultural Experiment Station at Manhattan, Kansas, recently conducted a series of experiments using ground limestone in non-leguminous cattle fattening rations. The results of these experiments over a three year period showed an advantage of adding calcium carbonate either as straight calcium carbonate or finely ground high calcium content limestone to

7. Riegel, Bmil Raymond--Industrial Chemistry, p. 96. 
a calf fattening ration consisting of corn, cottonseed meal, cane silage, and prairie hay. In another experiment the tests showed the possibility of using silage alone as the roughage portion of cattle fattening rations when supplemented with a high calcium content powdered limestone. Iimestone for use in cattle fattening rations should contain a minimum of 95 percent calcium carbonate. ${ }^{8}$ Limestone suitable for cattle feeding in Flis County is found only in the Fort Hays member of the Niobrara formation. Four of the ten samples taken from the Fort Hays member ran above 95 percent calcium carbonate which indicates that a plentiful supply of limestone of cattle feeding quality is available in this county.

At the present time the most important economic use of the rock of the Upper Cretaceous System of this county is that of building stone. Most of the churches of the county and the buildings on the campus of the Fort Hays Kansas State College are built of native stone. The Fort Hays limestone member and the Greenhorn limestone formation yield a grade of stone that has proved very satisfactory for building purposes.

As can readily be seen the natural resources of this county in regara to its rock deposits are great. We may say that the

8. Dr. C. W. MeCampbell, Professor of Animal Husbandry, Kansas State College of Agriculture and Applied Science, in answer to written inquiry. 
natural resources in this regard far outweigh the present need. Generally speaking, the lime content of the rock of the Upper Cretaceous system in this county is high, but the lack of ready market and the high cost of transportation to industrial centers makes the economic value at present in most instances only a dormant possibility. 
50 .

B I B L I O G R A P H Y

1. Bass, N. W. Geologic Investigations in Western Kansas. 96 p. (In Kansas State Geological Survey Bulletin 11, Lawrence, Kansas.)

2. Engelender, Carl J. Elementary Quantitative Analysis. New York, John Wiley and Sons, 1929, 68-130.

Contains a good laboratory outline for the volumetric analysis of limestone.

3. Hillebrand, W. F. Analysis of Silicate and Carbonate Rock. 285 p. (United States Geological Survey. Department of Interior. Bulletin No. 700.)

Used for general reference on rock analysis.

4. Pirrson, Louis V., and Schuchert, Charles. A Textbook of Geology. New York, John Wiley and Sons, 1929. 488 p.

A general reference book on geology. 
5. Riegel, Emil Raymond. Industrial Chemistry. New York, The Chemical Catalog Company, 1928, 90-96. of raw products.

6. Talbot, Henry P. Quantitative Chemical Analysis. 7th. ed., revised and rewritten by L. F. Hamilton and S. G. Simpson. New York, The Macmillan Company, 1931, 184-198. 